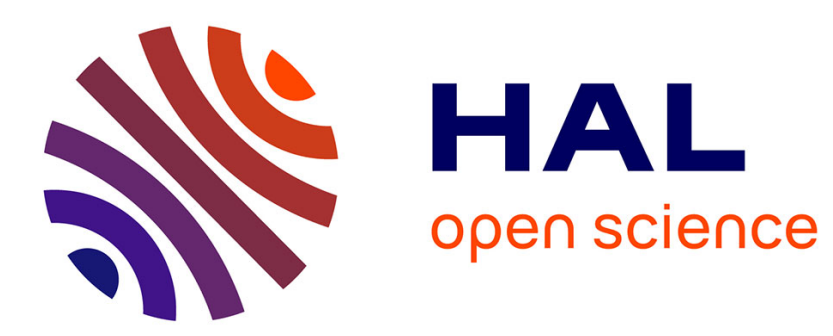

\title{
Basal body movements as a mechanism for mitochondrial genome segregation in the trypanosome cell cycle
}

\author{
Derrick R Robinson
}

\section{- To cite this version:}

Derrick R Robinson. Basal body movements as a mechanism for mitochondrial genome segregation in the trypanosome cell cycle. Nature, 1991, 10.1038/352731a0 . hal-02105728

\section{HAL Id: hal-02105728 \\ https://hal.science/hal-02105728}

Submitted on 21 Oct 2019

HAL is a multi-disciplinary open access archive for the deposit and dissemination of scientific research documents, whether they are published or not. The documents may come from teaching and research institutions in France or abroad, or from public or private research centers.
L'archive ouverte pluridisciplinaire HAL, est destinée au dépôt et à la diffusion de documents scientifiques de niveau recherche, publiés ou non, émanant des établissements d'enseignement et de recherche français ou étrangers, des laboratoires publics ou privés. 
Received 4 June; accepted 2 July 1991

1. Albritton, L. M., Tseng, L., Scadden, D. \& Cunningham, J. M. Cell 57, 659-666 (1989)

2. Weiss, R. A. in RNA Tumor Viruses (eds Weiss, R., Teich, N., Varmus, H. \& Coffin, J.) 209-260 (Cold Spring Harbor Laboratory, New York, 1984).

3. Handelin, B. \& Kabat, D. Virology 140, 183-187 (1985)

4. Christensen, H. N. \& Liang, M. J. biol. Chem. 241, 5542-5551 (1966).

5. Christensen, H. N. Meth. Enzym. 173, 576-616 (1989).

6. White, M. F. Biochim. biophys. Acta 822, 355-374 (1985).

6. White, M. F. Biochim. biophys. Acta 822, 355-374 (1985).

7. Kabat, D. Virology 171, $464-474$ (1989).

9. Christensen, H. N.. Handgloten, M. E. \& Thomas, E. L. Proc. natn. Acad. Sci. U.S. A. 63, 948-955 (1969).

10. Christensen, H. N. Biochim. biophys. Acta 779, 255-269 (1984).

11. White, M. F., Gazzola, G. C. \& Christensen, H. N. J. biol. Chem, 257, $4443-4449$ (1982).

12. Moore, J. P., Keating, J. A. M. Norton, W. A. \& Sattentau, Q. J. J. Virol. 65, 1133-1140 (1991)

3. Hoffmann W biol Chem 260, 11831-11837 (1985)

14. Nikawa, J., Hosaka, K. Tsukagoshi, Y. \& Yamashita, S. J. biol. Chem. 265, 15996-16003 (1990) Tanaka. G. R. \& Fink, G. R. Gene 38, 205-214 (1985).

6. Segal, S. \& Thier, S. O. in The Metabolic Basis of Inherited Disease (eds Scriver, C. R., Beaudet A. L., Sly, W. S. \& Valle, D.) 2479-2496 (McGraw-Hill, New York, 1989).

17. Stevenson, M. Meier, C., Mann, A. M., Chapman, N. \& Wasiak, A. Cell 53, 483-496 (1988).

18. Delwart, E. L. \& Panganiban, A. T. J. Virol. 63, 273-280 (1989).

19. Rein, A. Virology 120, 251-257 (1982).

. DeLarco, J. \& Todaro, G. J. Cell 8, 365-371 (1976)

1. Sommerfelt, M. A. \& Weiss, R. A. Virology 176, 58-69 (1990)

2. Kabat, D. in Current Top. Microbiol, Immun, 148, 1-42 (1989)

3. Inle, J. H., Rein, A. \& Mural, R. in Advances in Viral Oncology Vol. 4 (ed. Klein, G.) 95-137 (Raven. New York, 1984).

24. MoGrath. M. S., Pillemer, E. Kodistra, D. \& Weissman, I. L. Contemp. Top. Immunobiol, 11, 157-184 (1980)

25. Mitani et al. Proc natn. Acad. Sci. US.A. 84, 237-240 (1987)

26. Cianciolo, G. J., Copeland, T. D.. Oroszlan, S. \& Snyderman, R. Science 230, 453-455 (1985)

27. Kleinerman, E. S., Lachman, L. B., Knowles, R. D., Snyderman, R. \& Gianciolo, G. J. J. Immun. 139 2329-2337 (1987)

28. Sitbon, M. et al. Cell 47, 851-859 (1986)

29. Szurek, P. F., Yuen, P. H., Jerzy, R. \& Wong, P. K. Y. J. Virol. 62, 357-360 (1988)

30. MacLeod, C. L., Finley, K., Kakuda, D. Kozak, C. A. \& Wilkinson, M. F. Molec. cell. Biol. 10, 3663-3674 (1990).

31. O'Hara, B. et al. Cell Growth Differ, 1, 119-127 (1990).

ACKNOWLEDGEMENTS. Supported by the NIH. We thank J. Cunningham (Harvard Medical School) for the ecoR cDNA and Yan-Na Wu for injecting oocytes.

\section{Basal body movements as a mechanism for mitochondrial genome segregation in the trypanosome cell cycle}

\section{Derrick R. Robinson \& Keith Gull*}

Department of Biochemistry and Molecular Biology. The Medical School, University of Manchester, Oxford Road, Manchester M13 9PT, UK

THE mitochondrial genome of Trypanosoma brucei is organized in the form of a complex catenated network of circular DNA molecules. This mass of DNA, known as the kinetoplast, is present at a unique site in the single mitochondrion, and is replicated in a discrete, periodic $S$ phase of the cell cycle. The single-copy nature of the kinetoplast suggests that there is a mechanism ensuring segregation fidelity of replicated copies to each daughter cell. Historically, speculation regarding the nature of this mechanism has often attributed significance to the close association between the kinetoplast and the flagellum basal body. We provide here direct evidence that this mitochondrial DNA complex is indeed linked to the basal body, and segregation of the kinetoplast DNA is dependent on a microtubule-mediated separation of the new and old flagellar basal bodies during the cell cycle. This unique system may represent the remnants of an evolutionarily archaic mechanism for genome segregation.

Light-microscope descriptions of the trypanosome cell comment on the coincidence of location of the flagellar basal bodies and the kinetoplast. Phase-contrast microscopy illustrates this architecture showing an elongated trypanosome cell with a single flagellum (Fig. 1a); the single nucleus and kinetoplast are revealed by DAPI staining (Fig. $1 b$ ). Electron microscopy reveals that the mitochondrion runs the length of the elongated

* To whom correspondence should be addressed. cell and that the kinetoplast is always next and orthogonal to the basal body (Fig. 1c) ${ }^{1}$.

In a definitive description of haematoxylin-stained trypanosome cells, Robertson observed these relationships ${ }^{2}$, although the precise identity of the structures was not known. She noted the structural coincidence of the two organelles and discussed the possibility that one may exert a segregational effect on the other during cell morphogenesis. Many authors have subsequently reiterated this hypothesis ${ }^{3-8}$. Although there has been considerable improvement in our understanding of the function and organization of these organelles there is still little insight into how the trypanosome cell accomplishes the segregation of these single-copy organelles during cell division. We have used specific probes to locate each organelle, and when combined with drug intervention experiments these reveal the nature of the segregation process.

We labelled trypanosome cells with two monoclonal antibodies which particularly allow detection of both the flagellum and the basal bodies. We chose the ROD1 (ref. 9) antibody as it detects the paraflagellar rod (a structure that runs alongside the flagellar axoneme) at the point of its emergence from the cell to the flagellar tip. This leaves an unlabelled region between the proximal end of the paraflagellar rod and the basal bodies, allowing simultaneous visualization of the basal bodies by the monoclonal antibody BBA4 (ref. 9). These probes reveal the high-order precision of organelle position and replication during the cell cycle. It is possible to determine the position of a cell in the cell cycle by scoring criteria such as the presence of a new flagellum, the relative length of old and new flagella and the distance apart of basal bodies (Fig. $2 a, c, e)^{10}$. DAPI staining of these cells also reveals the position both of the nuclei and of the kinetoplasts. (Fig. $2 b, d, f$ ).

To reveal dependency relationships between these movements we applied these probes to cells after treatments with drugs designed to compromise organelle segregation. First, we asked whether inhibition of the segregation of kinetoplast DNA affects basal body segregation. As the kinetoplast is a complex mass of catenated DNA molecules we reasoned that inhibitors of topoisomerase II should jeopardize segregation by inhibiting the decatenation-catenation mechanisms ${ }^{11-13}$. Independent application of two drugs, teniposide and ethidium bromide, to trypanosome cultures for periods just under the cell doubling time resulted in the appearance of cells that possessed stretched
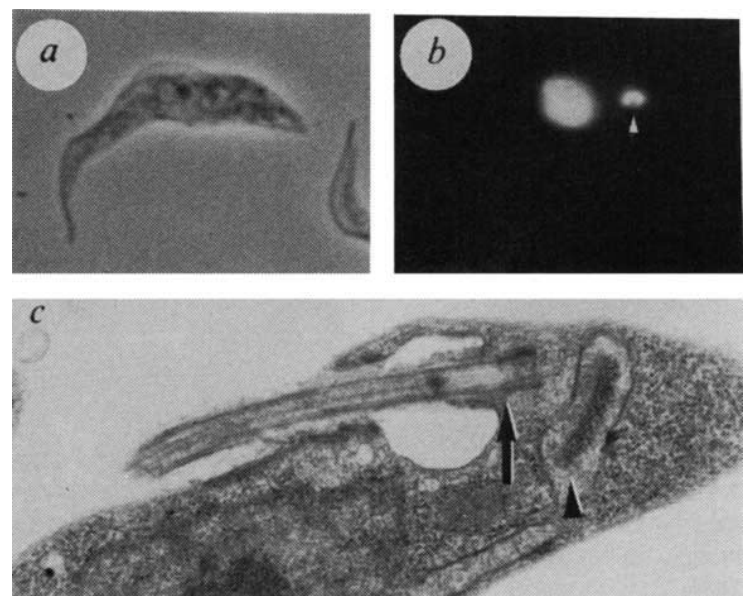

FIG. 1 Visualization of the intimate association between flagellar basal bodies and the mitochondrial genome in T. brucei. a. Phase-contrast micrograph of a culture form trypanosome. $b$, Identical cell stained with the DNA-intercalating dye DAPI (4,6-diamidino-2-phenylindole; Sigma) reveals the large nucleus and the smaller kinetoplast. $c$. Electron micrograph of a trypanosome sectioned longitudinally, displaying orthogonal alignment of kinetoplast with the flagellum basal body. $c$, Arrow indicates the basal body; $b$ and $c$, arrowheads indicate kinetoplasts. 
masses of kinetoplast DNA (Fig. $3 b, d$ ). Immunofluorescence using the two monoclonal antibody probes shows that such cells have relatively long new flagella and that the basal bodies have separated essentially as normal. Interestingly, the basal bodies are located at the poles of these stretched kinetoplast structures, (Fig. $3 a, c$ ). Thus, although this treatment compromises the segregation of the kinetoplast DNA, it does not seem to affect basal body segregation.

Second, does the separation of basal bodies influence kinetoplast segregation? We used a concentration of the antimicrotubule drug ansamitocin $(2 \mu \mathrm{M})$, which halts basal body separation by inhibiting microtubule cytoskeletal morphogenesis ${ }^{14}$. This concentration of ansamitocin does not seriously affect growth of the new flagellar axoneme. Examination of cultures after such drug treatment revealed cells with the unusual morphology seen in Fig. $3 e$ and $f$. Such cells have produced long new flagella and yet the basal bodies of the old and new flagella have not moved apart. The cell in Fig. $3 e$ is such an example in that it has a relative flagella length ratio (new to old) of 0.47 . In a control cell this should signify that the basal bodies would be separated by about $2.7 \mu \mathrm{m}$. In fact, the basal bodies are still juxtaposed (Fig. $3 e$ ). Although the kinetoplast DNA complexes have replicated, as represented by an approximate duplication of DAPI staining, they have not segregated (Fig. $3 f$ ).

We interpret the above experiments as providing direct evidence that the basal bodies do indeed mediate the efficient
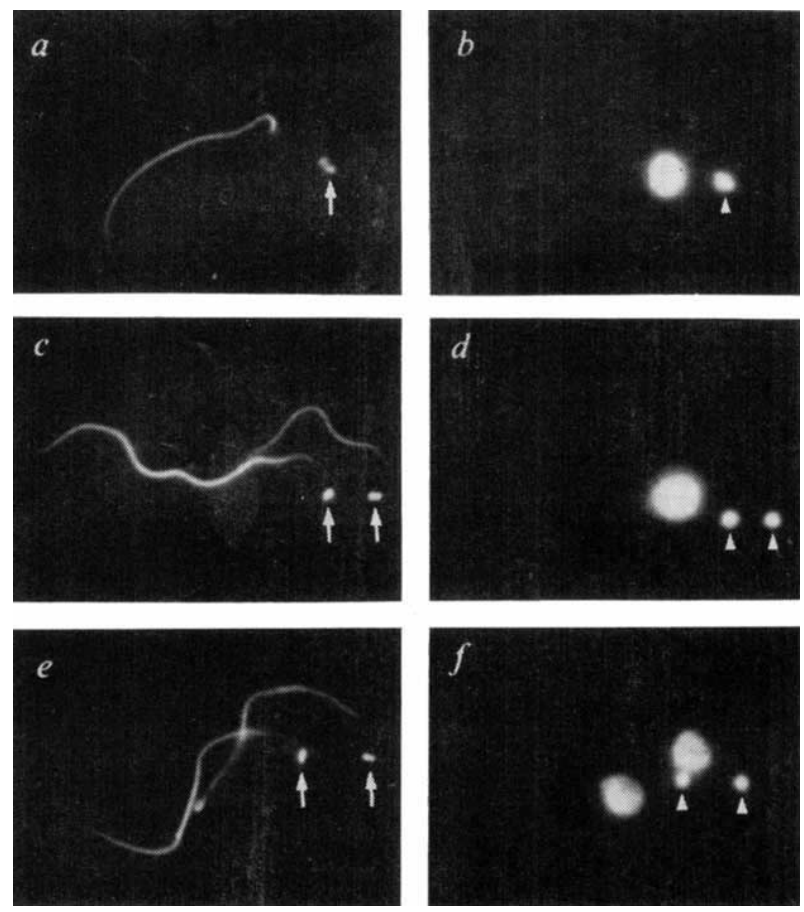

FIG. 2 Flagella and kinetoplast organization in the cell cycle of $T$. brucei, a, $c$ and $e$. Photomicrographs of trypanosomes labelled with ROD1 and BBA4 monoclonal antibody probes, viewed using fluorescence microscopy. Note the development of the new flagellum coincides with the separation of the replicated kinetoplasts, seen when viewed after DAPI staining $b$, $d$ and $f$. Arrows indicate basal bodies; arrowheads indicate kinetoplasts.

METHODS. Asynchronous early to mid-log phase culture cells (3-4) $10^{6} \mathrm{ml}^{-1}$ T. brucei strain 427 ), were grown at $28^{\circ} \mathrm{C}$ in SDM79 supplemented with $10 \%$ fetal calf serum ${ }^{15}$, and collected by centrifugation at $1,000 \mathrm{~g}$ for $10 \mathrm{~min}$. Immunofluorescence is essentially as in ref. 16. Briefly, cells are washed in PBS ( $\mathrm{pH} 7.4$ ), settled on slides, fixed in methanol at $-20^{\circ} \mathrm{C}$ for $60 \mathrm{~min}$, rehydrated in PBS, and incubated with a 1:1 mixture of mouse monoclonals ROD1 and BBA4 for $60 \mathrm{~min}$. After incubation cells are washed, incubated in rabbit anti-mouse FITC conjugate diluted 1:40 in PBS, stained with DAPI, mounted in Mowiol 4-88 and viewed by phase contrast and fluorescence microscopy. segregation of the mitochondrial genome complexes in $T$. brucei. Such a mechanism therefore suggests the presence of some form of link between the two organelles. At its most extreme such a link might be envisaged as 'molecular hard wiring' between the mitochondrial matrix and a cytoplasmic organelle. We have tested the possibility that such a connection exists by isolating flagella and showing that kinetoplast DNA remains attached to their proximal (basal body) ends. First, we have used a protocol which involves hypotonic lysis and depolymerization of the subpellicular microtubule array by the addition of a high concentration of $\mathrm{Ca}^{2+}$. This results in a population of flagellakinetoplast complexes, with the kinetoplasts still tightly associated with the basal bodies (Fig. $4 a$ ). Second, we extracted cells with a buffer containing Triton X-100, a nonionic detergent which solubilizes membrane components, leaving a cytoskeleton. Again, solubilizing the subpellicular microtubule corset allows isolation of a flagella preparation exhibiting attached kinetoplast DNA complexes (Fig. $4 b$ ), thus suggesting that membranous structures are not an absolute requirement for maintenance of this unique association.
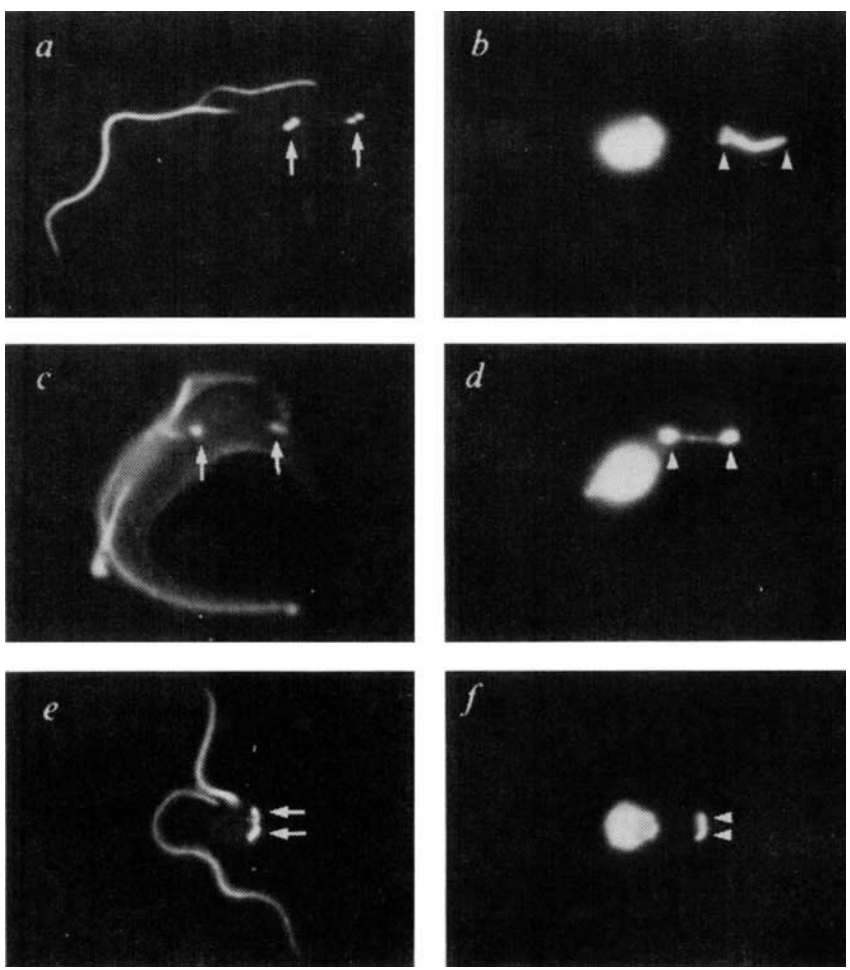

FIG. 3 Drug treatment of cultured trypanosomes reveals processes involved in kinetoplast segregation. a, Immunofluorescence photomicrograph of a cell treated for $8 \mathrm{~h}$ with ethidium bromide, final concentration of $500 \mu \mathrm{M}$, and labelled with ROD1 and BBA4. $b$, Same cell as in $a$, viewed after DAPI staining. The kinetoplast DNA is stretched between the separated basal bodies. $c$ $d$, A cell treated with teniposide for $8 \mathrm{~h}$, final concentration of $200 \mu \mathrm{M}$. Antibody labelling and DAPI staining as a. Note again that 'normal' kinetoplast segregation is impeded. $e, f$, Immunofluorescence photomicrographs of a cell treated with ansamitocin for $7 \mathrm{~h}$, final concentration $2 \mu \mathrm{M}$. Antibody labelling and DAPI staining as a. Basal body and kinetoplast segregation has been halted. Arrows indicate basal bodies, arrowheads indicate kinetoplasts.

METHODS. Culture form $T$. brucei, strain 427 , are grown to early mid-log phase $3-4 \times 10^{6} \mathrm{ml}^{-1}$ at $28^{\circ} \mathrm{C}$ as previously described. Topoisomerase II poisons: ethidium bromide solubilized in SDM79 was added to the culture to a final concentration of $500 \mu \mathrm{M}$ for $8 \mathrm{~h}$ at $28^{\circ} \mathrm{C}$. The cells are then washed twice in PBS and treated for immunofluorescence. Teniposide solubilized in DMSO (dimethyl sulphoxide) was added to a culture, final concentration of $200 \mu \mathrm{M}$ for $8 \mathrm{~h}$ at $28^{\circ} \mathrm{C}$. The cells are then washed twice in PBS and treated for immunofluorescence. Microtubule poisons: ansamitocin solubilized in DMSO was added to a culture to a final concentration of $2 \mu \mathrm{M}$ for $7 \mathrm{~h}$. The cells are washed twice in PBS, and treated for immunofluorescence. 

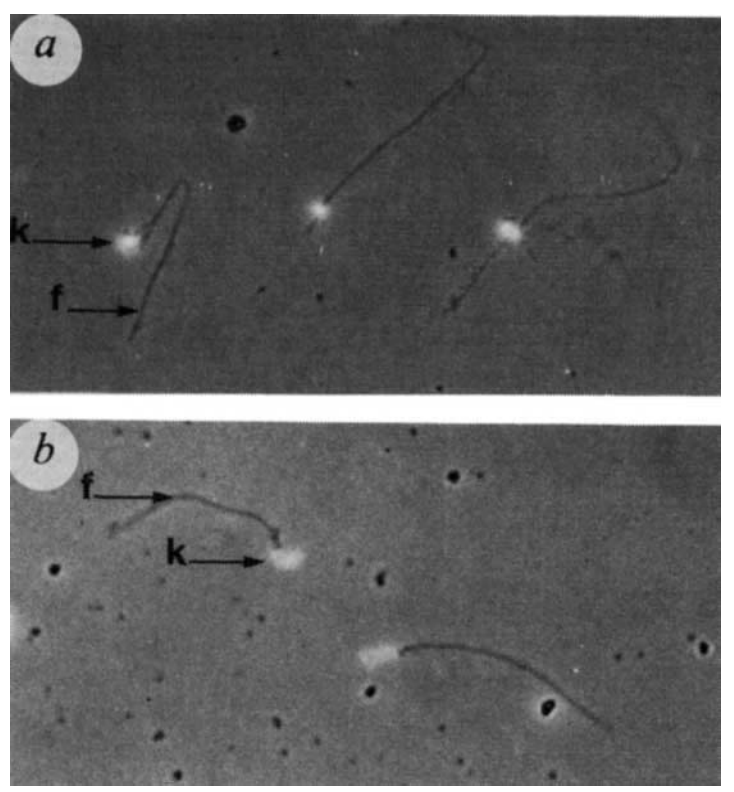

FIG. 4 Combined phase-contrast and DAPI fluorescence micrographs of isolated T. brucei flageila show kinetoplasts (bright fluorescent dots) still attached to basal bodies. a, Flagella isolated by hypotonic lysis and cytoskeletal depolymerization. $b$. Flagella isolated by detergent lysis and cytoskeletal depolymerization. The isolated flagella (f) and DAPI stained kinetoplasts $(k)$ are viewed by combined phase-contrast/fluorescence microscopy.

METHODS. Hypotonic lysis: log-phase cell cultures were collected by centrifugation, washed three times in $0.25 \mathrm{M}$ sucrose, $20 \mathrm{mM}$ Tris- $\mathrm{HCl}, \mathrm{pH} 7.9$. Microtubule cytoskeletal depolymerization and cell lysis was achieved by resuspending and incubating cells in $3 \mathrm{mM} \mathrm{Ca}^{2+}$ in double distilled water for $3 \mathrm{~h}$ at $4^{\circ} \mathrm{C}$. Detergent lysis: EDTA was added to a mid-log phase culture, $4-5 \times 10^{6}$ cells $\mathrm{ml}^{-1}$, final concentration of $5 \mathrm{mM}$. Cells were then collected by centrifugation, washed in PBS, resuspended on ice for $10 \mathrm{~min}$ in extraction buffer, $10.5 \%$ Triton X-100 in PMN (10 mM NaH $\mathrm{PO}_{4}, 150 \mathrm{mM} \mathrm{NaCl}, 1 \mathrm{mM}$ $\left.\mathrm{MgCl}_{2} \mathrm{pH} 7.2\right)$ ). Cytoskeietons were collected by centrifugation, washed in extraction buffer, and resuspended on ice for $45 \mathrm{~min}$ in $1 \mathrm{mM} \mathrm{Ca}^{2+}$ in PMN. Isolated flagella are DAPI-stained and viewed by fluorescence microscopy.

Our experiments reveal an established structural and func. tional link between the mitochondrial genome and basal bodies in the $T$. brucei cell. This link provides a means of ensuring high fidelity segregation of these single-copy cytoplasmic organelles to daughter cells. By contrast, other eukaryotic cells possess multiple and dispersed mitochondrial genomes which may not require such stringent segregation fidelity. The high-order system present in $T$. bruce $i$ may represent a remnant of an evolutionarily archaic mechanism for DNA segregation.

\footnotetext{
Received 5 June; accepted 27 June 1991.

1. Vickeman K. Trans. R. Soc. trop. Med. Hyg. 56, 487-495 (1962).

2. Robertson, M. Phil. Trans. R. Soc. B203, 161-184 (1913)

3. Simpson, L. . Protozool. 15, 132-136 (1968).

4. Molyneux, D. H. Parasitology 59, 55-66 (1969)

5. Lewis, D. H. J. Protozool. 22, 344-352 (1975).

6. Steinert, M., Van Assel, S. \& Steinert, G. in Biochemistry of Parasites and Host-Parasite Relationships (ed. Van den Bossche, H.) 193-202 (Elsevier/North-Holland Biomedical, Amsterdam. 1976).

7. Souto-Padron, T., De Souza, W. \& Heuser, J. E. L. Cell Sci. 69, 167-178 (1984).

8. Hiruki. T. Zentbl. Bakt Mikrobiol. Hyg. 264, 392-398 (1987)

Woods, A. et al. J. Cell Sci 93, 491-500 (1989).

D. Sherwin, T. \& Gull, K. Phil. Trans. R. Soc. B323, 573-588 (1989)

1. Chow, K. C. Macdonald, T. L. \& Ross, W. E. Molec Pharmacol 34, 467-473 (1988)

2. Patel, S., Austin, C. A. \& Fisher, L. M. Anticancer Drug Des. 5, 149-157 (1990)

3. Shapiro, T. A. \& Englund. P. T. Proc. natn. Acad. Sci. U.S.A. 87, 950-954 (1990)

4. Ootso, K. et al. Cancer Res. 40, 1707-1717 (1980)

15. Brun. R. \& Schonenberger. M. Acta trop. 36, 289-292 (1979).

16. Sherwin. T., Schneider. A., Sasse, R., Seebeck. T. \& Gull, K. J. Cell Biol. 104, 439-446 (1987).
}

ACKNOWLEDGEMENTS. We thank L. M. Fisher for teniposide. Ansamitocin was a donation from Takeda Chemical Industries of Japan. D.R. is supported by the SERC and this investigation received support from the UNDP/World Bank/WHO special programme for Research and Training in Tropical Diseases.

\section{Cloning of an NF- $\kappa$ B subunit which stimulates HIV transcription in synergy with p65}

\author{
Roland M. Schmid, Neil D. Perkins, Colin S. Duckett, \\ Philip C. Andrews \& Gary J. Nabel*
}

Howard Hughes Medical Institute, Departments of Internal Medicine and Biological Chemistry, University of Michigan Medical Center, Ann Arbor, Michigan 48109-0650, USA

* To whom correspondence should be addressed

THE transcription factor NF- $\kappa$ B is a protein complex which comprises a DNA-binding subunit and an associated transactivation protein (of relative molecular masses $50,000(50 \mathrm{~K})$ and $65 \mathrm{~K}$, respectively) ${ }^{1,2}$. Both the $50 \mathrm{~K}$ and $65 \mathrm{~K}$ subunits have similarity with the rel oncogene and the Drosophila maternal effect gene dorsal $^{3-6}$. The 50K DNA-binding subunit was previously thought to be a unique protein, derived from the $105 \mathrm{~K}$ gene product ( 105 ). We now report the isolation of a complementary DNA that encodes an alternative DNA-binding subunit of NF- $\kappa$ B. It is more similar to p105 NF- $\kappa$ B than other family members and defines a new subset of rel-related genes. It is synthesized as a $\sim 100 \mathrm{~K}$ protein (p100) that is expressed in different cell types, contains cell cycle motifs and, like p105, must be processed to generate a $50 \mathrm{~K}$ form. A $49 \mathrm{~K}$ product (p49) can be generated independently from an alternatively spliced transcript; it has specific $\kappa$ B DNA-binding activity and can form heterodimers with other rel proteins. In contrast to the $\sim 50 \mathrm{~K}$ protein derived from $\mathrm{p} 105$, $\mathrm{p} 49$ acts in synergy with p65 to stimulate the human immunodeficiency virus (HIV) enhancer in transiently transfected Jurkat cells. p49/p100 NF- $\kappa$ B could therefore be important in the regulation of HIV and other $\kappa \mathrm{B}$-containing genes.

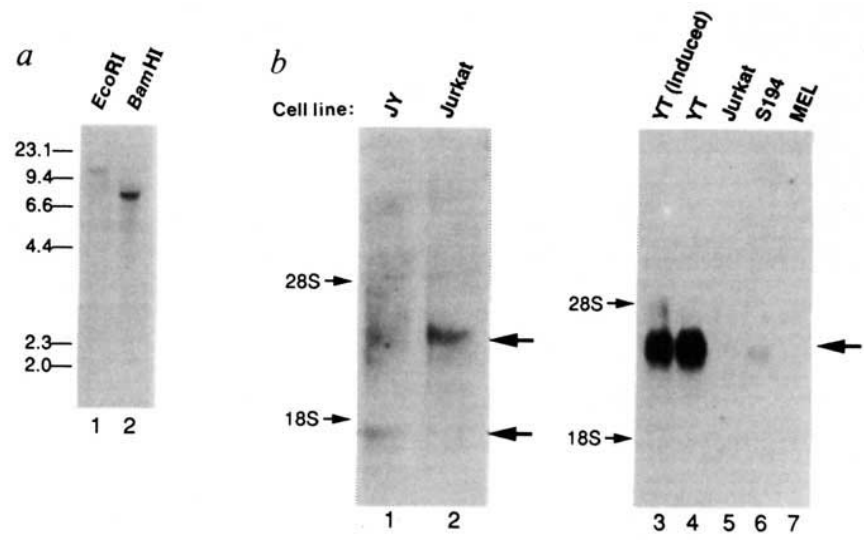

FIG. 1 DNA and RNA analysis of the p49 cDNA clone. a, Southern blot analysis of $p 49$ on human genomic DNA $(10 \mu \mathrm{g})$ cut with ECoRI (lane 1) or BamHI (lane 2). The DNA probe used was a 1,069-base-pair Bst XI fragment of $p 49$ which lacks both $5^{\prime}$-untranslated DNA and the repetitive region from the $3^{\prime}$ end of the clone. Molecular size markers (in $\mathrm{kb}$ ) are indicated on the left. $b$, Northern blot analysis of $10 \mu \mathrm{g}$ poly $(A)^{+}$RNA from $J Y$, an Epstein-Barr virus-transformed B-cell line (lane 1) (from J. Leiden), and the Jurkat $T$ leukaemia line (lane 2) using the BstXl fragment of p49 as a probe with GeneScreen Plus (DuPont). Another analysis was performed using $10 \mu \mathrm{g}$ poly $(A)^{+}$RNA from TPA-stimulated and unstimulated $Y T$ T leukaemia cells (lanes 3 and 4); the Jurkat T leukaemia line (lane 5); S194, a murine B cell line (lane 6); and the murine erythroleukaemia (MEL), cell line (lane 7), on a nitrocellulose filter. Migration positions of ribosomal RNA markers are indicated (28S and 185 ). Arrows denote specific hybridizable mRNA species of $1.9 \mathrm{~kb}$ (lanes 1,2) and $\sim 3.5 \mathrm{~kb}$ (lanes $1-7$ ). For each blot, comparable amounts of actin RNA were detected in all lanes using a human $\beta$-actin probe. 